\title{
Rights of Women in Islamic and Pakistan Law and Constitution
}

*Muhammad Akram Rana

\section{ABSTRACT}

Men and women are two important groups universally inhabiting all the societies. Pakistan is a patriarchal society where men dominate women in all aspects of life. Pakistani women's education, health and working condition lead to their subordinate status making them vulnerable to violence and crime. It further reduces women's chances to reach the decision making and authoritative positions in society, like head of the state.

In this article we will focus on rights of women in Islamic and Pakistani law and constitution. i.e

- What sort of law has been introduced in Pakistan, whether it is compatible to Islamic law or not?

- Family law ordinance 1961

- Hudood ordinance

- Zina ordinance

- Law of evidence

- The Honor killing Act 2004

- The Protection of Women Act 2006

- Laws of sexual Harassment

- Law to curb Acid attacks 2011

- The Anti Women Social Protection Act 2011

- Law on Domestic Violence

- The law on Child Marriage

Keeping in view all the laws and ordinances it will be assessed whether women's rights are protected and they are satisfied with their position in the society.

It is also said that the laws are mainly formulated by men dominated political and legislative institutions. The study of laws and legislative procedures and justice systems for impact on women will also help to improve the status of women.

This paper will discuss laws in Islam and Pakistan, whether they have improved the condition of women or otherwise.

Keywords: Islam, Law, Legislation, Rights, Institutions, Women, Protection, Constitution

* Professor (R), 110-C, Bahauddin Zakariya University Teachers Colony, Multan Public School Road, Multan. 


\section{Rights of Women in Islamic and Pakistani Law and Constitution:}

The question of Muslim Women's rights Continue to occupy central stage throughout the Islamic world. Pakistani women's poor education, health and work force participation lead to their subordinate status making them vulnerable to violence and crime. It further reduces women's chances to reach the decision making and authoritative positions in society. Thus, women are marginally represented in political and legislative forums. (1) This study shows that it is no longer possible to deprive Muslim women of their Islamic and human rights.

\section{History of women rights in Muslim World:}

From the $19^{\text {th }}$ century revolutionary changes in social and economic structure began to take place and new generations of Muslims began to feel great need for fresh thinking on issues of Shariah laws. Napoleon's invasion on Egypt brought it under French influence and Egyptian society in the Muslim world became the hub for intellectual debates on women's rights. Many books were written out of which Al-Marrah`Al-Muslimah was the most stimulating. In India too, many Muslim scholars like Sir Syed Ahmad Khan, Mawlvi Mumtaz Ali Khan, Justice Amir Ali and Mawlvi Chiragh Ali began to re-think on Shariah Laws pertaining to women's rights. Thus modernity and modern changes directly impingend on the Muslim thinking and some scholars began to advocate changes in the traditional Shariah Laws. However, majority of the women still remained deprived of modern education and confined to their homes. But it was the post independence situation in Pakistan which began to bring fundamental changes in the attitudes of Muslim women (2)

\section{Women's Rights in Islam:}

The issue of women's rights in Islam is the topic of great misunderstanding and distortion partly due to lack of understanding but also partly due to misbehavior of some Muslims which had been taken to represent the teachings of Islam in the past. Here we will examine rights of women one by one given by Islam.

\section{Spiritual Point of View:}

According to the Quran Men and Women have the same spirit. There is no

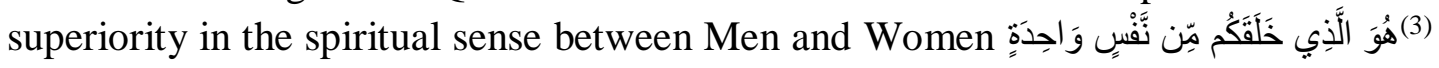
In terms of moral, spiritual duties, acts of worships, the requirements of Men and Women, all the same, except in some cases when Women have certain concessions because of their feminine nature or their health or the health of their babies. The Quran explicitly specified that whoever does good deeds, and is a believer (Male or 


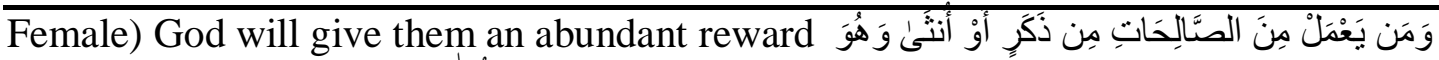

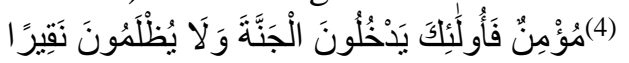

\section{Economic Rights:}

In Europe until the $19^{\text {th }}$ Century women did not have the right to own their property. When they were married, either it would be transferred to the husband or she would not be able to dispense of it without permission of her husband. Britain, perhaps, The first country gave property rights to women, the law made in 1860 was known as "married women property act". More than 1300 years earlier that right was clearly established in Islamic Law (5)

\section{The Quran explicitly remarked:}

"Whatever men earn, they have a share of that and whatever the women earn

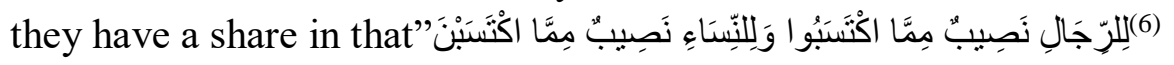

There is no compulsion in Islamic Law that Women cannot work out side home or have a profession of such kind that they can work only in the home. In fact, by definition in a truly Islamic society, there must be women who are physicians, Nurses, teachers, because it is preferable also to separate teen agers in the volatile years in secondary schools education. And if she likes to work, she is entitled to equal pay for work of equal worth. When it comes to financial security Islamic Law is better in many respects towards women. During the period of engagement and marriage she receives gifts and consequently owns them. If she has happened to have property during or before marriage she is the sole owner of that property. She needs not to spend a single penny for the requirements of household. The full maintenance and support of married women is the entire responsibility of her husband, even though she might be richer than her husband. She also enjoys certain guaranties during her waiting period. If she has children she is entitled to have children support. She is given the right to inherit from her Parents property. She receives amount of dowry from her husband. As already said above she is entitled to work outside the house, if she is in need of that. Thus we can say that she is free to involve herself in economic activities.

\section{Social Status:}

From the matrimonial point of view the Quran clearly states "Among his signs is this, that he created for you mates from among yourself that you may dwell وَ وَمِنْ آَيَاتِهِ

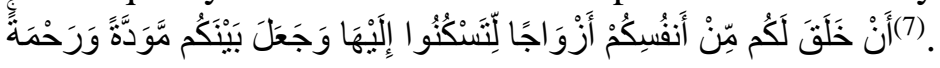


Approval and consent of the girls for marriage is a prerequisite for the validity of marriage in Islam. She has the right to say Yes or No to a query which is put before her. Woman can't be forced to marry without her consent if she is forced to do so then her marriage is void. It is reported that the Prophet (PBUH) said "A widow or divorcee should not be married before her consent is sought". "No virgin is to marry without first consulting her and her approval is her silence" (8)

It is reported once a married girl came to the Prophet (PBUH) complaining that her father gave her hand to a man without her consent. The prophet said she has the choice between accepting the marriage and rejecting it. The girl said "I accepted this marriage but I wanted to let women know that father's have no right to force husbands on them (9) This tradition indicate that she has the power to enjoy free will to exercise.

Monogamy is the norm for Muslims. The only verse speaks about polygamy limiting not instituting polygamy. The verse was revealed after the battle of Uhad in which many Muslims were martyred.

Concluding one remarks that under social rights she also has rights to inheritance, dowery, and maintenance during waiting period and child upbringing. She has the right to move from her house. She can visit her Parent's house; she can participate in battle fields, etc.

\section{Legal Rights:}

She enjoys some legal rights:

1. Rights to be equal before Law

2. Right to witness

3. Right to Vote

4. Right to work on political and legal position

These rights are self evident and need not to be explained. 
Right to Entertainment:

She has the right to witness entertainment events. Once Hazrat Ayesha (RTA) showed desire to see the ongoing circus in the street. Holy Prophet (PBUH) happily replied her that she can hide herself at the back of Holy Prophet (PBUH) and then watch the circus. Aisha did this and enjoyed the circus as long as she could stand there. When became tired she went back to home. The Holy Prophet (PBUH) stood there for more than one hour for her entertainment. We can infer from this event that women have the right of entertainment, as Hadith is the second source of Islamic Law.

\section{Right to Be Consulted In All Matters}

Women's have right to be consulted in all family matters. Many people believe that it is folly to act or listen women's advice. In fact they themselves are disbeliever and unaware to the Sunnah of the Prophet (PBUH). It is well known tradition that in the event of Hudabiya Holy Prophet (PBUH) consulted Hazrat Umm e Salma (RTA) and acted on her advice to move on. (10)

By summing up the whole discussion on rights of women it can be said that Islam is the first deen that embraces women with all social, economical, legal and political rights. It is very unjust if anybody is blaming Islam in the present state to suppress the women. In fact it is not Islam to be blamed it is because of forgetting the teachings of Islam.

Now we see how women enjoy their rights in the constitution of Pakistan. Fundamental Rights in the Constitution and Elimination of Discrimination

Fundamental Rights are equally applicable to men and women. Article 15 of the constitution allows freedom of movement to all citizens equally irrespective of their Gender. To achieve this objective the constitution of Pakistan explicitly out laws any kind of discrimination on the basis of sex, covering all aspects of social life in general. Equality among men and women in terms of employment and services are also maintained in article 27 of the constitution of Pakistan. Besides maintaining equality in terms of law, service, and social life, the Constitution takes necessary measures for the protection of women in Pakistani society. (11)

As per principles of policy of the constitution of Pakistan, the state encourages women, peasants and workers to take active participation in local bodies elections. Similarly, steps are taken for women to take active part in national life. The state takes measures to protect women, their children and family life .The state also eradicates social evils like, illiteracy, prostitution, gambling, drugs, obscene 
literature .The state secures well being of the citizens including women.(12) These are the basic principles on which the whole building of Constitution was erected. Let's discuss family laws prepared for the welfare of the women.

\section{Muslim Family Law Ordinance 1961:}

The Muslim Family law ordinance 1961 also adopted some of the recommendations of the commission on Marriage and Family constituted in the year 1955. The ordinance governs the main aspects of Muslim women's family lives rules as succession, registration of marriage, polygamy, divorce, dissolution of marriage otherwise than by divorce, maintenance, dower, etc in the following manner as discussed in detail:

\section{Succession:}

The section 4 of the ordinance related to succession clearly provided that in case of the death of any of the parents, children will receive their due share from their Grandparents. This is hot debated issue in Islamic society but this ordinance resolves this issue thus.

Registration of Marriage:

The section 5 of the ordinance makes it obligatory for all the citizens of Pakistan whose marriages are done under Muslim law compulsorily get their marriages registered.

\section{Polygamy:}

No man during the subsistence of an existing marriage shall, except with the previous permission in writing of the Arbitration council, contract another marriage, nor shall any such marriage contracted without such permission is registered under their ordinance. This measure is being adopted for the welfare of the women and to protect their conjugal rights.

\section{Talaq:}

Any man who wishes to divorce his wife shall, as soon as may be after the pronouncement of talaq in any form what so ever, give the chairman a notice in writing of his having done so, and shall supply a copy thereof to the wife. However, Shariah does not recognize this method of registration. Islamic ideology council has given verdict on this contrarily.

\section{Dissolution of Marriage otherwise then by Talaq:}

Where the Right to divorce has been duly delegated to the wife and she wishes to exercise those rights, the provisions of section shall apply. This is age in one of the issue which helps women to be free from the burdens of marriage if they 
are not satisfied with their marriage having certain reasons recognized by the Moral values.

\section{Maintenance:}

If any husband fails to maintain his wife adequately, or where there are more wives than one, fails to maintain them equitably, the Arbitration council may issue a certificate specifying the amount which shall be paid as maintenance by the husband. This clause is also in front of women.

\section{Dower:}

Where no details about the mode of payment of dower are specified in the nikahnama, or the marriage contract, the entire amount of the dower shall be presumed to be payable on demand. Concluding we remove, though these provisions of family law are contrary to Islamic law, yet these are adopted for the betterment of women.

\section{Islamic Law and women in Pakistan:}

\section{Hudood ordiance:}

Offence of Zina and Qazaf fall under Hudood ordinance, we have to see how this ordinance affected women? And what measure has been taken in view of that. The Pakistan penal code before the promulgation of zina ordinance was defining only men as the possible offender of the crime of rape against women. But the new ordinance, unlike PPC, included women as possible perpetrator rape and adultery crimes. This inclusion of women as perpetrators is made through the use of words like a man and women are said to commit zina willfully...in section 4 of the ordinance.

This inclusion of women as a perpetrator of the crime of rape and adultery in this way is usually claimed as an opening to new ways for women's victimization through falls accusations of adultery (13) This has affected women very much and is discusses by advance circles and human activist and feminists.

The term validly married used in section 04 section 06 of the ordinance also became problematic with the potential of adding to the misery of women in Pakistani society where the functioning conditions of the systems of assembling of vital statistics is poor. The condition of proving valid marriage became a problem for women, (14) the rights given in family law ordinance 1961.

Therefore, it became easy to blame any woman without registered marriage of adultery .The same accusation was easy to be placed against women without a registered divorce when she re-marries. (15) 
It was noticed and declared that the ordinance failed to distinguish between the two crimes of rape and adultery having different.

Similarly, the ordinance also established the same criteria for requirement of proof of these two different crimes to be liable to Hadd in section 98 of the Ordinance. The requirement of Muslims adult male witnesses stated in section 08 (b) excluded women's testimony as proof for formic of hadd punishment in the case of Zina or Zina-bil-Jabar. There was no consideration mention are evidence based on medical examination or any other kind of proof for the punishment. Therefore, it was highly criticized in the society and learned circles.

It was very difficult for women rape victims to fulfill harsh requirements of providing evidence of rape. Similarly, the same difficulty for women's victims became facilitating for the preparatory to escape from punishment at all or at least from maximum Hadd punishment. Most rape trials were treated under Tazir, because of non- availability of required proof for Hadd punishment.

In a number of rape trials, the woman complaining of rape have been convicted of Zina because she could not prove that her unexplained pregnancy was the consequence of rape.(16)

\section{Law of Evidence:}

Section 8 (b) of the law ordinance was specifically asking for four Muslim adult truthful male who abstained from major sin to serve as eye witness for the act of penetration to prove zina or rape reliable to Hadd. This provision of the Zina ordinance was accepted in the section 17 (2) of the law of Evidence 1984, which acknowledged and enderorsed the exlusion of women from becoming eligible to serve as an eye-witness in the cases of rape and zina reliable to Hadd.(17).

Human rights watch has criticized the law of Evidence or Qanun-e-Shahadatpromulgated in 1984 for giving men and women unequal rights by assigning different work to their testimonies.

\section{The Honor Killing (and Vani) Act (2004):}

Pakistani and Islamic both laws do not allow the killing of women for such so called crimes. Islam has given injunctions for Zina allegations. If the culprit woman is other then wife four witness are to be provided. And if she happened to be wife the procedure of "liaan" is recommended. In Pakistan both the houses, national assembly and the senate passed the criminal law amendment Act 2004. The act was an effort to control violence and improve women conditions being murdered in the name of honor. For the first time in Pakistan, this act recognized in traditional social practices 
of honor killing known as karokari, come siyah-kari, tour as offences against human body in the section 299 (II) of PPC. The Act 2004 restricts the exchange of female as Vani and described to punishment for the person conducting such an exchange of women for settlement of disputes as rigorous imprisonment which may extend from three to ten years. This provision, if properly implemented will certainly discourage the even custom of Vani and Swara.(18)

\section{Protection of Women Act (2006):}

The amendments done in Hudood Ordince were significant to protect women from exploitation and victimization after 2002. The Act was called women Protection Act 2006. Weiss said that aim of these amendments was to made laws and procedures easily and facilitating for women victim and to protect them from being a convict of Zina, if they fail to prove the rape crime against themselves (19)

The major amendment is that it distinguished between zina and zina biljabar. It removed all the rape related provisions from zina ordinance and the justifications of Shariah courts and again placed them under PPC'S section 375 to be dealt with, while civil courts as they were before the promulgations of Hadood Ordinances (20). It clearly said that rape is an offence committed by a man against the woman. Evidentiary requirements of four male witnesses were also excluded. This act restricted the exposition of women to prosecution for adultery, if they fail to prove the rape crime against them. Further, to lessen the misery of women with unregistered marriage and divorce in rural areas the world 'valid' is removed from the phrase "valid marriage". To facilitate further women who are falsely accused for zina, the Act made the crime non-cognizable, so that the accused women may not suffer in prison during trial. The act removed whipping and stoning from all kinds of punishments prescribed in Zina Ordinance except that of Zina liable to Hadd.(21)

The Protection against Harassment of Women at the Workplace Act 2010 What is Harassment..? It means any unwelcome sexual advance, request for sexual favor or other verbal or written communication or physical conduct of a sexual nature, for sexually demanding attitudes, causing interference with work environment, or the attempt to punish the complaint for refusal to comply to such a request or is made a condition for employment.

There are three significant manifestations of harassment in the work environment:

1. Abuse of authority

2. Creating a hostile environment 
3. Retaliation

The amendments in PPC'S section 509 were introduced. Above mentioned three manifestations of harassment at work place are to be explained here.

The employees are responsible to ensure implementation of this act by incorporation of the code in their management policy and founding an inquiry committee within their organizations to investigate the complaints of harassment. The committee must included three members at least one of them should be women, one member of management and one employees representative. The failure to do so may cause a penalty of twenty thousand to one hundred thousand rupees to the employer. The respective governments are also bound to appoint an ombudsman at the federal and potential level to hear these complaints. The act also defined minor and major penalties for the person proved guilty committed this crime.

\section{Law to Curb Acid Attacks:}

Section 332 and 337 of PPC's were dealing with the hurts of human body and compensation respectively.

The protection of human from disfigurement by Acid throwing act of 2011 was promulgated on $28^{\text {th }}$ Dec. 2011. This was to curb the growing incidents of disfigurement of women by acid attacks. Amendment included disfigurement of face or dismemberment of other parts or organs of human body. New section 336-A was added. It included every kind of acid, poison, explosive, or explosive substance, heating substance, noxious thing, arsenic or any other chemical which has corroding effect and which is deleterious to human body.

The punishment prescribed for such crime was imprisonment of life or imprisonment of either description which shall not be less than 14 years and fine 01 million rupees in section 336 (b) added for the purposes.

The Anti-Women Social Practices Act (2011)

Anti-women social practices included:

1. Force Marriages

2. Marriage with the Quran

3. Marriage in exchange for vengeance (vani)

4. Deprivation of women's inheritace.

The Anti-Women social practices were recognized by introducing Act of 2011 (No XXVI of 2011). It also added to the punishment for such crimes a fine of five hundred thousand rupees along with an imprisonment from three to seven years. Law of Domestic Violence: (2012) 
The domestic violence (prevention and protection) Act 2012 was passed from both houses on $20^{\text {th }}$ February 2012. The act in its section 4 explicitly included "All acts of gender based or other physical or Psychological abuse committed by a responded against women children or other vulnerable persons with whom the respondent is or has been in a domestic relationship. It is, however, criticized that despite the using term sexual abuse it does not define spousal rape or marital rape as a part of domestic violence. (22)

The Punjab assembly also passed a bill on domestic violence on $24^{\text {th }}$ Feb. 2016. The Governor of The Punjab Province signed it. The act provided toll free number to access the authorities. The victim women were protected from being thrown out of the house, as per this law. The man could be made to leave the house for two days. It must be noted that this act is heavily criticized by the religious political parties. They declared it western conspiracy to break the sacred institution of family.

The Law on Child Marriage:

The major causes of child marriages are considered:

1. Poverty

2. Illiteracy

3. Poor social cultures

4. Religious practices

Age in the History of Child Marriage Act:

1. The Child marriage Pakistan Act 1929, Girl 14 Years and Boy 18 Years.

2. Family Law ordinance, Girl 16 Years and Boy 18 Years.

3. Sindh Child Marriage Restraint Act 2013. Girl 18 Years and Boy 18 Years.

4. Punjab Marriage Restraint Act 2015. Girl 16 Years and Boy 18 Years.

The formulation of proper law and its proper implementation to all human beings on equal basis may help to improve women's position.

\section{Conclusion:}

Islam has given numerous, rather all rights to women. If we look in the historical context when women were deprived of all human rights, it seems that the women became privileged class of the society after Islam gave them all rights. As time goes on, enlightment spreads in Europe and other parts of the world including Islamic territories. Feminist movements began to through light on the human rights 
especially of women advantages to give equal rights to women as those of men. They were successful theoretically but failed to do so in practice. In Pakistan despite the constitutional commitments to gender equality, women are still suffering and are deprived of their social, economic and political rights. They are still less educated, less employed \& less represented in political institutions. Controversy still exists whether she can go out of the house or not. She can vote or not. She can become head of the state or otherwise. One must, however, think that Islam as a deen has separate identity; it cannot follow European or American life style. It is pure religion and wants to keep chastity of women. Therefore we have to be very careful in following the footsteps of Europe and their feminist movements.

However, we have to acknowledge the rights given to them by our religion Islam. Social structure must not become hindrance while utilizing these rights. They are equally part of human life. They shamed not be barred from accruing their rights. 


\section{References}

1. NaimaTabassum, Dr., Women in Pakistan, Higher Education Commission Pakistan, Islamabad, 2016, P. vii.

2. Asghar Ali, Engineer, The Quran, Women and Modern Society, New Dawn Press UK. 2005 PP. 4-5

3. Quran, 7: 189.

4. Quran, 4: 124

5. Www.css.forum.com.pk

6. Quran, 4: 32

7. Quran, 30-20

8. Ibn-e-Majah Sunan Ibn-e-Majah, translated by Qasim Ameen, Maktaba al-Ilm, 18-Urdu Bazar Lahore, Kitab al-Nikah, P26, Hadith No. 1870.

9. Bukhari, Muhammad b.Ismail, Sahih Bukhari, Islami Kutub Khana, Urdu Bazar Lahore, Kitab al-Nikah, Bab 113, Hadith No. 2938.

10. Akram, Rana, Muhammaed al Rasullah, Beacon Books, Multan, 2004. P-102.

11. Naima Tabassum, Dr., Women in Pakistan, Higher Education Commission Pakistan,

12. Ibid P.226

13. Lau, M, twenty-five year of hudood ordinances-A, review. Washington and Law Review, 64(4) 2007, 1291-1314

14. Yefet, K. C. What's the constitution got to do with it? Regulating marriage in Pakistan. Duke Journal of Gender Law \& Policy, (2004), 347-377

15. Ibid P.375

16. Naima Tabassum, Dr., Women in Pakistan, Higher Education Commission Pakistan P 16

17. Ibid P 242

18. Ibid P 246

19. Weiss, A.M. Moving forward with the legal empowerment of women in Pakistan USA United States Institute of Peace. 2012

20. Lau, M, twenty-five year of Hudood Ordinances-A, review. Washington and lee Law Review, 64(4) 2007, 1291-1314

21. Cheema M.H. Judicial patronage of honour killings in Pakistan: The Supreme court's persistent adherence to the doctrine of grave and sudden provocation, buffalo Human

Rights Law Review, 14, 51. Retrieved April, 42013 from http://papers.ssrn.com/sol3/papers.cfm?abstract id=1536258. (2008)

22. Shah, N.A Nasreen, S. \& Ali, A. (2010) Marital rape. Pakistan Journal for Gender Studies, 3, 53-63.

* We in debt to Naima \& Tabassum for her valuable information provider in this article. 